\title{
CHURCH DISCOURSE ON HIV/AIDS: A RESPONSIBLE RESPONSE TO A DISASTER?
}

\author{
Miranda N Pillay \\ Department of Religion and Theology \\ University of the Western Cape
}

\begin{abstract}
The HIV/AIDS epidemic continues to evolve and has now reached pandemic proportions in South Africa and other developing countries throughout the world. HIV/AIDS presents a challenge to the well-being of individuals and to the public health of proportions unprecedented in modern history. While the challenge is scientific and medical, it is also psychological, legal, economic, social, ethical and theological. It is no longer a question of "why" the church should respond but rather "how" the church ought to respond. When the churches' response to the HIV/AIDS pandemic is analysed within the framework of the disaster management continuum, one gains a schematic perspective of the current responses as well the gaps in such responses. ${ }^{l}$
\end{abstract}

\section{Introduction}

... the global HIV/AIDS epidemic, through its devastating scale and impact, constitutes a global emergency and one of the most formidable challenges to human life and dignity, ... it undermines social and economic development throughout the world and affects all levels of society - national, community, family and individual. Africa, in particular sub-Saharan Africa, is currently the worst-affected region... (UN General Assembly Special Session on HIV/AIDS June 2001).

This quotation aptly reflects the disaster facing all of humanity, and in particular SubSaharan Africa which is not only the most affected by HIV and AIDS, but also the least prepared and able to deal with the effects the disease has on the lives of individuals, families and communities. ${ }^{2}$ Dealing with the impact and challenges of HIV and AIDS on a medical and social level proves to be a daunting if not near impossible task particularly in South Africa's rural areas. ${ }^{3}$ It is estimated that around 4,7 million South Africans are currently HIV positive and this number is growing by 1800 new infections every day. Approximately 200000 South Africans already have AIDS. ${ }^{4}$ Statistics lay bare in a dramatic way the impact of Southern Africa's "stalking" disaster.

1. The United Nations International Decade for Natural Disaster Reduction Programme launched in Geneva, Switzerland in 1990, coupled with the concept of sustainable development that emanated from the Earth Summit in Rio de Janeiro in June 1992, and the subsequent paradigm shift in dealing with disasters highlight the need to implement proactive measures that would lessen the impact of a disaster, if it cannot be avoided at all (Holloway 1999:3; Disaster Management Training Programme 1992:12).

2. While some countries in this region have launched comprehensive and collaborative responses to the pandemic, the South African government directed its resources and energies in debating the proverbial "causes of the fire while Rome is burning".

3. Added to the fact that many rural people are economically disempowered, limited or no access to resources such as medical treatment and care, transport, running water and sanitation worsens their plight.

4. I will not be dealing with characteristics of the HI virus and the pathogenisis of AIDS in this article. See Chapter 2 of WCC Study Document Facing AIDS: The Churches' Response. See also Nicolson (1995:9-17) and Snidle (1997:916) for an overview in this regard. 
HIV/AIDS is indeed an "equal opportunity" disease. Yet those who are economically and socially marginalised are more vulnerable. The social and economic impact of this disease, which knows no age, race, class, gender religion or sexual orientation, is felt by thousands of South Africans living with AIDS, millions of South Africans who are infected, and all South Africans who may or may not acknowledge that they are affected. ${ }^{5}$

There has been an awakening to the realities of the pandemic among churches of which many have projects and programmes on HIV/AIDS in place. ${ }^{6}$ Many churches in various communities are doing a lot of "caring" work and have regular "awareness" workshops on HIV/AIDS and its impact on the lives of those affected and infected. ${ }^{7}$ There is, however, still a deafening silence from some church groups who believe the disease is "out there" while others adopt a judgmental approach believing that HIV/AIDS is God's punishment for sinful behaviour. ${ }^{8}$ Public pronouncements about what the church ought to be doing also reflect some churches' response to the challenges around HIV and AIDS. The Anglican Archbishop of Cape Town, Njongonkulu Ndungane, made the following appeal during the 59th Session of the Diocesan Synod of the Diocese of Cape Town during August 2000:

Until and unless we begin to measure the pandemic in terms of broken hearts, orphans, fear, loneliness, pain and grief, we will not adequately respond to a disease which is impacting on all of humanity.

What Ndungane is calling for is an important "phase" in the church's response to the HIV/AIDS pandemic. The churches' response of care, compassion, embrace and service is vital in terms of reacting appropriately to the pandemic and is indeed part of what the church ought to do. Physical, emotional and spiritual care for persons infected and affected together with awareness campaigns and workshops have contributed toward "breaking the silence" and reducing discrimination and stigmatization.

However, a shift toward a proactive phase is imperative if we hope to respond adequately and responsibly to a disease which impacts on all of humanity - a disease that challenges the church ethically and theologically. A further challenge is to ensure that the position of church leadership does not only remain that of broad public statements but that the necessary space for creative opportunities is made among its followers for "changing an ethic of death, arising out of fear and self-defensiveness to an ethic of life".

This article sets out to show that, by reflecting on church (and possibly other) responses to the HIV/AIDS pandemic, within an analytical framework of a disaster management continuum, an ethic of responsibility becomes a pivotal concept. Some ethical and theological challenges facing the church are highlighted, which could serve as "entry points" towards a responsible response to the HIV/AIDS pandemic.

5. As reported in the media earlier this year, some (politicians) are of the opinion that the "attention" given to HIV/AIDS is causing unnecessary alarm and that it is in the interest of all if ignored. Conspiracy theories have also entered the debate, suggesting that the focus on Africa is a racist slur and that pharmaceutical companies are out to enrich themselves while "poisoning" people with toxic drugs. These views as expressed by Peter Mokaba, ANC MP (among others) have resulted in intense debate among politicians and the citizenry of South Africa.

6. Nicolson (1995:7) contends that the churches' slow response is understandable if one considers that other problems in South Africa, especially the injustice, the violence and the political volatility, seemed more immediately urgent. There are other reasons for the churches' slow response - and continued reluctance of some churches - including the (previously held) view that AIDS is a homosexual disease or that AIDS is God's judgement on the sexual impurities of homosexuals and promiscuous people, who "deserve" it.

7. For a concise overview of the clinical and social epidemiology of HIV and AIDS, see Saayman (1991:157-166).

8. For some Christian theorists' views in this regard see Saayman (1991:159).

9. Mouton (1995:234) cites this as one of the challenges for the church, arising out of her understanding of Niebuhr's theology and ethics. 


\section{Managing a disaster responsibly}

A disaster is described as a progressive or sudden, widespread or local, natural or humancaused occurrence which:

(a) causes or threatens to cause

(i) death, injury or disease

(ii) damage to property, infrastructure or the environment or

(iii) disruption of the life of a community; and

(b) is of a magnitude that exceeds the ability of those affected by the disaster to cope with its effects using only their own resources (Republic of South Africa:1999).

Diagram 1 illustrates the disaster management continuum as an analytical framework for responding to disasters. Historically, typical disasters such as fires and floods in the informal settlements on the Cape Flats were managed by responding to the aftermath, and dealing with the consequences of such incidents. This response is indicated as the reactive phase on the continuum. The three basic stages in the reactive phase are, the immediate response stage, typified by wailing sirens and flashing lights of emergency vehicles; a relief stage which may include the provision of comfort services such as emergency sheltering, food, clothing and trauma counselling; the recovery stage which includes the provision of alternative short term accommodation, social relief funds paid to displaced families, etc.

While the reactive phase of disaster management remains an integral part of responding to emergencies and disasters, there has been a worldwide paradigm shift over the last decade, toward employing proactive strategies within disaster management circles (Jegillos 1999:7-16). The three basic stages in the proactive phase are the, preparedness stage which involves training people in communities to deal with disasters, having in place procedures such as contingency plans, public education, early warning systems, etc; the mitigation stage signifies measures taken to reduce the risk, vulnerability and impact of a disaster such as firebreaks to prevent the spread of fire; the prevention stage includes measures taken to avert a disaster, or stopping an occurrence from becoming a disaster. This may include measures aimed at preventing overcrowding at sports or public events, the building of a dam to prevent flooding, etc.

Diagram 1 captures the integrated approach of responding to a disaster, incorporating both a reactive and a proactive phase within the Disaster Management Continuum as illustrated in the White Paper on Disaster Management (Republic of South Africa 1999:32).

Proactive phase

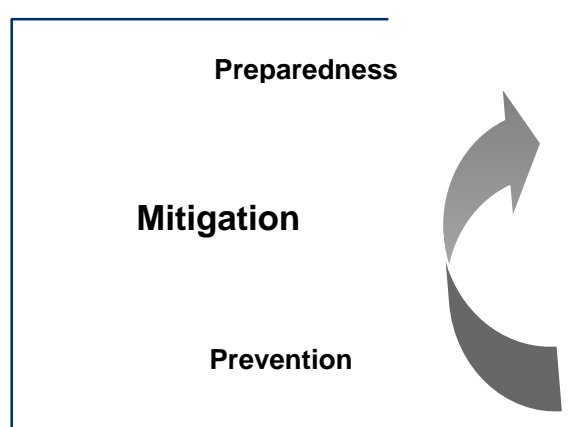

Diagram 1

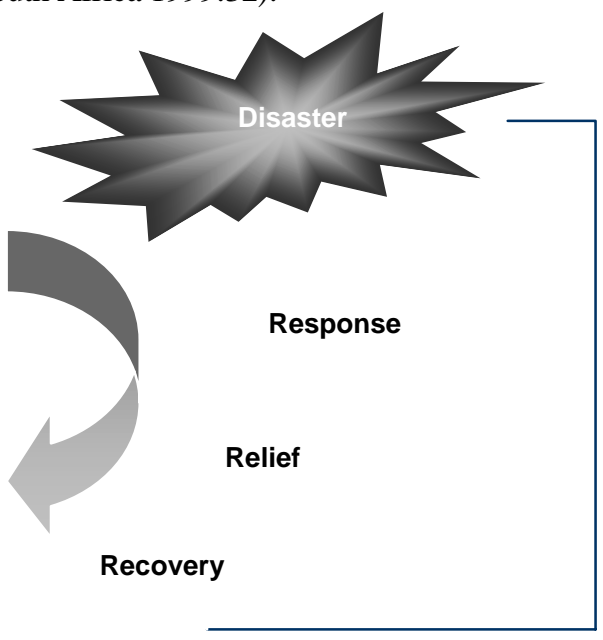

Reactive phase 
Considering the definition of a disaster, it is clear that HIV/AIDS can be considered a disaster. Diagram 1 provides an analytical framework, indicating that responding to a disaster effectively would require a strategy that encompass relief and prevention measures in a collaborative effort, involving various disciplines. The challenge facing the church as it responds to the AIDS pandemic, is to engage in proactive strategies that reflect an ethic of responsibility.

The churches' response which includes pastoral care, home-based care, AIDS education in the form of information workshops, planting of vegetable gardens and income generating workshops, as well as adding its voice to the Treatment Action Campaign's struggle for affordable anti-retrovirals, the condom debate and the (Anglican) ABC campaign, can generally be viewed as reactive measures, though it could be argued that some of the programmes may also be seen as being proactive.

\section{Responding responsibly}

The final responsible question is not how I can heroically pull myself out of the whole affair, but how a future generation is to go on living (Smit 1991:24 quoting Bonhoeffer).

This quotation reflects two primary concepts operative within an ethic of responsibility, which implies that responsibility is about collective, anticipatory actions. Responsibility has become a central theme in moral theology according to Curan (1976:157) who cites three contributory factors. Barthian theology played an important part in setting the theological scene for the development of an ethic of responsibility by viewing humankind primarily as beings who listen to and respond to the word of God. ${ }^{10} \mathrm{~A}$ second factor is the "way in which theology today perceives man (sic) in terms of his life in the world..." and that "... man (sic) is called to co-operate in transforming himself, his destiny and his world" (Curan 1976:159). A third factor which influences the primacy of a model of responsibility is derived from an eschatology that gives more importance to humankind's existence in this world and sees it in greater continuity with the next world.

In his account of contributions made toward the project of an ethic of responsibility, Huber (1993:580) concludes that the theological debate up until now has largely been a response to Weber's approach of an understanding of responsibility that emphasises the "liability for future effects of present actions". Huber identifies a relational rather than a substantialist anthropology as a factor on which all theological ethics of responsibility hinges. ${ }^{11}$ Whereas a substantialist anthropology is typically rooted in the understanding of humans as rational beings, a relational anthropology has its exemplary formulation in the understanding of humans as responsive and therefore responsible beings. ${ }^{12}$ It is from this position, says Huber, that Luther develops his theological anthropology in relational terms, identifying the four relations in which human life takes place as being in relation to God, to other persons, to the world, to oneself. An ethic of responsibility, which has as its basis the "human person as responder", has developed from a relational anthropology. ${ }^{13}$ In this regard, profound contributions have been made by Bonhoeffer and Niebuhr who both

10. Niebuhr (1963:126) states that an ethic of responsibility affirms that: "God is acting in all actions upon you. So respond to all actions upon you as to respond to his action."

11. The Enlightenment paradigm with its overemphasis on the rational individual is still dominant, says Saayman (1991:26) when he eludes to a "communal ethic" in which the African view of health and illness is embedded.

12. Hauerwas, according to Vosloo (1997:303), also criticizes the presumptions of the Enlightenment, which locates morality in rationality.

13. Christian ethics continues to be communal in nature, though community life may take on different shapes and functions over time and space (Mouton 1995:188). 
identify two different structures of relationship in responsibility, namely a responsibility "to" and a responsibility "for" God and others. In his own contribution to the understanding of a responsibility for, Huber explains:

We tend to interpret "responsibility for" simply as care, as caring for someone. Parents, teachers and politicians, interestingly enough, are the central examples of responsibility in Bonhoeffer and Jonas. Of course "responsibility for" includes care, but it means more than that. It is not simply care (Fürsorge) but prospective care (Vorsorge). Not the instinct of care, but the specifically human capacity to anticipate the future constitutes "responsible for"... not only the care that is evoked in me by the presence of the other, but the prospective care for the future of a shared realm of living together defines responsibility (1993:582).

Linked to the above explanation is Huber's contention that what is basic for human responsibility is "the capacity to anticipate real possibilities in the future and to make a choice among them." Huber suggests that we should consider what future impact our present actions may have, not only on our lives, but also on the lives of others. "Looking out" for or considering the "other" does not imply that one relinquishes power. Responsibility says Huber, "does not mean powerlessness but a reflexive use of power: it is the ability to gain power over one's power" (Huber 1993:583).

Over the centuries humans have prided themselves in having "power" to negotiate and find solutions to problems in their lives and the world. The quest to control economies, territories, individuals, groups and nations has proved successful for some but with grave consequences of disempowerment, alienation and vulnerability for others. Now humanity is faced with the realities of HIV and AIDS for which there is no cure or effective vaccine, despite relentless efforts in biomedical research. HIV/AIDS has been described as a behavioural disease and is perpetuated by social behavioural patterns that are maintained by social, economic, cultural and spiritual factors. ${ }^{14}$ I would thus argue that the power to stop the spread of HIV/AIDS in its disastrous tracks hinges strongly on making responsible decisions and choices. Primarily, but not simply, every individual is challenged to make responsible choices about his or her sexual relationships. Here I hasten to add that in some cultures women are not at liberty to negotiate sexual practices, and for many women the notion of choice is a luxury they cannot afford. However, an adequate response to the HIV/AIDS pandemic requires the involvement of every person and every organization - the government, medical and legal fraternities, pharmaceutical companies, businesses, communities, faith communities, families and individuals. It requires a comprehensive, collaborative effort rooted in the collective and anticipatory principles operative in an ethic of responsibility. I agree with Saayman (1991:27) who insists that the emphasis should be on "helping people develop a sense of collective responsibility for dealing with AIDS, as well as inculcating the conviction that something can be done about this life-threatening disease". It is my belief that Christians have both the "conviction of life" and a "spirit of community" to embody a vision and the will to respond in a way that will enable us to move from a situation of hopelessness and despair to hope and joyful living.

14. See Saayman (1991:159 - 163); Love Life Report (2001:6); Nicolson (1995:16-17).

15. Here Saayman quotes from Contact. Journal of the Christian Medical Commission, World Council of Churches, Geneva. No 117. Dec 1990. Emphasis mine. 


\section{Taking Responsibility: Toward a theology of hope}

In a continent that is fast dying, watching its youth overtake their elders to the grave, we desperately need a theology of resurrection ... Who will roll down the stone for us? God's accompaniment is assured (Tsele 2002).

We are indeed assured of God's accompaniment. Shouldn't we then all say, "Here I am Lord, send me"? For too long the church has been prompted by forces from outside to act or react. For too long it has depended on "guidance" from secular society. "Who will roll the stone for us?" We must roll the stone for ourselves! We have locked up within a tomb of suffering and death, the power of resurrection to life. We must take ownership of the grave and its stone cover to reclaim the Christian resources of love, mercy, grace, forgiveness, care, compassion and of community, of hope ... of life!

There is not a hint in the Gospels that Jesus relied on external control for moral or personal integrity. He found the locus of good and of evil within the human heart and he thrust awesome freedom and responsibility upon his followers. The challenge for the church is to ensure that the ethical position of its leadership does not remain broad public statements and official policy documents, but that church policy is implemented in such a way that it may shape the thoughts and lives of its members.

The church is in a unique situation to use the Christian symbol of community as revealed in the Trinity to bring about a "newness of mind" regarding relationships among its followers. It has become crucial for the church to reclaim its "potential" sources of moral formation rooted in Scripture, history and life-experiences of followers past and present. The Bible has the potential to influence the ethos of Christian communities in South Africa because once texts "penetrate deeply into the psyche, especially the collective psyche, they cease to be primarily objects of study and rather come to supply the conceptual and imaginative vocabularies, as well as the grammar and syntax with which we construe and construct reality" (Smit 1991:57). Thus the Bible influences the moral world because it shapes the way people see their world and how they speak about their world. Christians can reach reasonable judgement and decisions in many cases of ethical conduct by developing traditions of responsible biblical interpretation that manifests itself in liturgy and worship. ${ }^{16}$

Christian worship has ethical implications for public life because worshippers learn to see the world in a certain way. While Christian worship provides creative opportunities for affirming how "we see" God, ourselves, others and the environment, in which and with which we interact, it also provides the unique opportunities to help us "look in the right direction". The task to see, describe and respond to the world rightly is at the heart of the process of transformation in moral decisions and actions (Smit 1997:262). It is within the "space" created during worship that the opportunity exists for the changing of the hearts and minds of Christians.

During worship, Christians remember God's great act of love and because of this remembrance of God's salvific love, there is hope. This creative tension between past and future allows for transformation in the present.

Local congregations are communities of people who come together to worship in fellowship. This opportunity to affirm, guide and transform a Christian ethos should not be underestimated or missed. I would thus argue that one way, if not the only way, the church

16. Mouton (1994:21) reminds us that the Bible does not supply direct, simple answers to moral questions, but that we have the obligation to involve ourselves in the creative tension of the liminal space between the dynamics of the biblical texts and the needs of contemporary society. At this time, in South Africa, the need to respond responsibly is a matter of urgency. 
could ensure that its response to HIV and AIDS does not remain broad public statements or official church documents, is to allow its response to be embodied during worship. ${ }^{17}$ It calls for a liturgy which creates the space and opportunity "to look in the right direction" in order to shape our thoughts, beliefs and actions in response to HIV and AIDS.

Churches are grounded in communities. Herein lies their strength and credibility to act effectively in response to the impact and challenges presented by the HIV and AIDS pandemic. It is within the space of the local church where people gather voluntarily that the spirit of community must be rediscovered, reclaimed and nurtured. It is within the community that life must be sustained and experienced to the full. I maintain that the challenges with which we are faced in our response to HIV and AIDS present us with an opportunity to be the community we ought to be.

The infrastructure to guide and transform a Christian ethos is already in place in local churches. Smit (1997:272) points out that Christian worship is an ambivalent phenomenon while it has the potential to change the way we see things, it can (and has been) used to avoid what we should see and thus to entrench the status quo. ${ }^{18}$ The Bible, according to Smit (1991:59), influences the imagination and language of society. It influences the way people "see" things; it influences their vision, their grasp of reality and history. ${ }^{19}$ There was a time when stories of the Bible, images and conceptual patterns permeated the culture of Christian communities. Fragments of this have penetrated into post apartheid South African society, where the Christian symbols of hope, peace and reconciliation stand firm.

My argument so far has been that despite the picture of a looming disaster painted by statistics on AIDS related deaths; despite the devastating social and economic impact it has on everyone - infected and affected - and despite the air of despair created by the fact that there is no cure for the dreaded disease, there is hope, because Christians have both a conviction of life" and "a spirit of community" rooted in the church as the resurrected body of Christ.

The power to stop the disease in its destructive tracks is the responsibility of every member within the body of Christ. However, this process can only start if we allow ourselves to see that our choices and actions reflect who we are, and that coming together in community during worship, gives us the opportunity to negotiate who we ought to be. I have also argued that an adequate and responsible response to HIV and AIDS would require the church to adopt a reactive approach as well as a proactive approach. AIDS does not present the church with new challenges but it challenges us to recover things that we have neglected or lost.

\section{Church discourse: Theological and ethical 'entry points'}

The HIV/AIDS pandemic presents the church with the challenge to create opportunities where people are inspired to "have life abundantly"; where people are encouraged to develop skills to make responsible, life-sustaining decisions that are congruent with their sense of Christian identity and where collective responsibility is fostered, offering an embracing spirit of community.

17. This is confirmed by Vosloo (1997:299) with reference to Botman who argues that: "within the South African context there is a need, not only for mere reconstruction by means of programmes, but for transformation as a result of discipleship".

18. This is particularly true of some churches' response during apartheid.

19. We should always keep in mind though, that the Bible had been used to legitimize slavery, racism, sexism and other discriminatory and exploitative perceptions and practices. 
What follows next, are areas of concern which I think the church should consider as theological and ethical "entry points" in its response to the HIV/AIDS pandemic.

\subsection{All of us are 'people living with AIDS' (PWA's)}

Until and unless we stop talking about AIDS as if it is "out there" we have no hope of addressing the alienating effect of stigmatisation. There is a tendency to refer to "people living with AIDS" also by the use of the acronym "PWA's" as if they were a group of people different to ourselves, creating an "us and them" situation. Other terms such as AIDS sufferers" and "AIDS victims" already proved to be undesirable and discriminatory. In my opinion, the term "scourge" should also be avoided since it implies that HIV/AIDS is a curse, a plague etc. The alienating effect that labelling has, contributes to the fact that people are reluctant to test for the HI-virus. Knowing one's HIV-serostatus is the first step toward a responsible response for the individual and community. ${ }^{20}$ The church, as a community, ought to embrace this fact. This, however, calls for an environment in which people will feel safe to "risk" knowing their status. A WCC Study Document (1997:64) reflects:

... HIV testing should be done only if informed consent of the person concerned has been obtained without any form of coercion or persuasion ... Moreover, testing before marriage, if recommended, must be voluntary on the part of both partners ... Voluntary testing is often requested by people who would like to know their HIV-serostatus to help them to make responsible decisions about their future lives ... and often also the lives of others (italics - MP).

While I generally agree with this statement, I would like to argue that the church finds itself in a position where it could (or maybe should) develop and enhance responsible decision-making skills without any coercion. This is also in line with "international agreement that the best way of prevention is providing information and seeking voluntary co-operation ..." (WCC Study Document 1997:64). I would further argue that the church could and should provide a "space" conducive to seeking voluntary co-operation and commitment to making responsible choices and decisions. ${ }^{21}$

However, the absence of a "safe space" will continue as long as the churches' response is embodied via workshops and information sessions held as an addendum or separate entity to the life of the church, and as long as we refer to "people living with AIDS" as if they were not part of our community. The community needs to sustain the individual, for ultimately the community will depend on the individual for its future existence.

20. The advantage of knowing one's serostatus is that it allows one to take responsible decisions regarding one's sexual behaviour and practices. For one who tests HIV negative, it implies the responsibility of making choices that will ensure that one remains negative. For one who tests positive it implies the responsibility that the disease is not spread, that effective treatment is sought and that choices regarding pregnancy can be made. Here I hasten to add that I do not have in mind "compulsory testing" which Nicolson (1995:49) makes reference to. I also recognize the fact that women who are economically dependant and sexually vulnerable and disempowered do not have the luxury of making such choices.

21. "Decision making for the Christian is not just personal but must also take into consideration the teaching of Christ. For too long we have had double standards - one for males and one for females, one for married and one for single now there's one for HIV-positive and HIV-negative or People Living with AIDS and People Not Living with AIDS" (Sindle 1997:64 - italics mine). 


\subsection{Safer sex or safe sex?}

The $\mathrm{ABC}$ approach (Abstinence, Be faithful, Condomise) to AIDS education is inadequate without an accompanying sexual ethic. Besides, it is my view that the $\mathrm{ABC}$ approach as it stands, implies that if one "condomises" one has failed to abstain, or one has failed to be faithful. This in itself may promote a reluctance to "condomise". This could be one of the reasons why the disease has continued to spread despite a vigorous campaign to promote the use of condoms as a means of practicing "safe sex". The value of abstinence or faithfulness to one's partner needs to be explored in new and creative ways. The church however, has to admit that it carries with it the historical baggage of viewing and teaching about sexuality in a negative way, giving the impression that sexual sins, especially premarital sex, matter more than most other sins (Nicolson 1995:20).

Avoiding all possible trappings of a simplistic, moralistic approach that promotes a legalistic, rule-based sexual ethic, churches have the responsibility to teach about sexual abstinence and about faithfulness. I agree with Saayman's argument that such teaching should include the promotion of "closed sexual relationships" as perhaps the only way to stop the spread of the HI virus. ${ }^{22}$ However, I hasten to add that it can only be successful if it is seen as a responsible response toward sustaining the "life" and "future life" of the community in particular, and humanity as a whole, of which all, whether HIV positive or HIV negative, are equal members.

\subsection{Poverty}

The link between HIV/AIDS and poverty has often been highlighted and the link between HIV/AIDS and economic benefits has already been established. ${ }^{23}$ As HIV/AIDS begin to affect the day-to-day quality of life of HIV-positive individuals and their families, it leads to increased absenteeism from work, also on the side of spouses and other members of the family. In many instances economic and social circumstances force children to leave school in order to look after a sick parent/adult. This phenomenon perpetuates the poverty cycle as there is a correlation between levels of education and standard of living. HIV/AIDS does not only threaten lives but also the sustainability of livelihoods of the poor and economically vulnerable.

While poverty does not cause HIV/AIDS, the poor and destitute are more prone to contracting the disease and in that sense poverty exacerbates the pandemic. Often the need to still one's hunger pangs, or to provide food for those who depend on one, is more urgent, real and sometimes life-threatening than the knowledge of possible dangers of a sexually transmitted disease. Poverty impacts on nutrition. The extremely poor often find it difficult to meet basic caloric requirements, let alone the particular mix of proteins and calories necessary to benefit optimally from Anti-Retroviral Therapy, that is, if they have access to these drugs. ${ }^{24}$ As access to treatment is further restricted by availability of adequate health care infrastructure, rural and urban poor populations suffer disproportionately. Their lack of

22. "Aids in Africa will not be successfully controlled by attempts aimed at making open sexual relationships as safe as possible ... A successful campaign against Aids will have to hinge on the issue of closed sexual relationships" (Saayman 1991:24).

23. See Saayman \& Kriel (1991:160); Nicolson (1995:39); WCC Study Document (1997:66).

24. Since 1996, People who are HIV positive have been treated with a combination of anti-retroviral drugs, known as Highly Active Anti-retroviral Therapy (HAART). This treatment stops HIV from multiplying and reduces the volume of HIV in the blood, slowing down the process that leads to AIDS. This, together with proper treatment for opportunistic infections such as oral thrush, shingles and TB, allow HIV-positive people to live normal, productive lives for up to 10 years (AIDS Law Project 2001:25). 
advantage makes their lives no less valuable and no less deserving of protection. Denial of treatment means suffering and death. A response that does not include addressing in concrete terms the realities suffered by the poor cannot claim to be credible or responsible.

\subsection{Life after HIV/AIDS?}

We now have consensus (among SA parliamentarians) that HIV does cause AIDS. This however does not mean that HIV equals AIDS. Testing HIV positive need not be a death sentence. People testing positive to the HI virus can continue to live positive, productive lives. An integral part of addressing the HIV/AIDS pandemic is to address the fear of death that has resulted in a numbness and reluctance to acknowledge and celebrate the gift of life. Moreover a "theology of life and death" has to include an urgent review of the historical understanding of sin and death. The perception that sexual indiscretion, infidelity and promiscuity are wrong insofar as the sin is visible - now, as a manifestation of AIDS and previously as pregnancy out of wedlock - has to be challenged. The irony is, in the case of AIDS, "sin" results in death to the body while in the case of pregnancy it brings forth life. The issues involving sex, and sin, and life, and death become more and more complex as the term "born to die" takes on new meaning, with the threat of mother-to-child HIV infection. There is a need to move away from reducing morality merely to sexual conduct.

Stigmatization, alienation and discrimination have in various instances proved to be the biggest "killer" in human history. It now perpetuates the spread of HIV/AIDS as people are reluctant to know their serostatus, let alone reveal it for fear of being rejected and ostracised by partners, family members, fellow workers, and communities - including some churches. We are reminded by Yeoman (1997:34) that, theology is a science and because theologies are human constructs, they reflect the origins and biases and interests of those who formulate them. Like all sciences, theology must change and develop with changing knowledge and experience. The church is challenged to develop a theology that reflects the life enhancing principles evident in the essence of Christianity.

\subsection{Family}

How do we respond in a situation where the elderly are burying young mothers and fathers, and children are left orphaned? HIV/AIDS changes family composition and the way communities operate. In the context of South Africa's burgeoning orphan population, how do we speak about family?

Children who are orphaned are usually accepted into the households of close relatives. But as the spread of HIV/AIDS continues, families are less able to absorb new members and the normal reciprocal help in communities may break down (Snidle 1997:3). The large numbers of anticipated AIDS orphans has led the UN children's Fund (UNICEF) to conclude that Africa's age-old social safety net for orphaned children - in the form of deeprooted kinship systems and extended family networks - is unable to cope with the strain of AIDS and soaring numbers of orphans (UNICEF December 1999:3).

HIV/AIDS has enormous emotional, psychological, economic and social consequences, not only for the person who is HIV-positive or has AIDS, but also for the whole family. Shock, bewilderment, anger, disbelief, social isolation and despair are normal ways of responding to any life-threatening disease but it seems to have generated a different nuance with the way the HIV/AIDS pandemic has been responded to (Snidle 1997:86). 


\subsection{Gender}

While HIV/AIDS may be described as an "equal opportunity" disease, the economic and sexual vulnerability of many women have been identified as the main reasons for increase in infections among women. Women in Sub-Saharan Africa are now worst affected by the HIV/AIDS pandemic and as infections rise in women, so do infections in the infants born to them, with one in every three babies born to HIV-infected mothers becoming infected themselves. The pandemic is fuelled by the sexual and economic subordination of women. If a woman is poor, then long-term health risks may seem irrelevant to her own or her family's survival. This may explain why prevention strategies that are limited to "knowing the facts" and "becoming aware of the risk" have not succeeded.

Women, and particularly South African women, who are still suffering the discriminatory effects of apartheid and who are continuously struggling against gender power relations are experiencing a triple jeopardy in their vulnerability to HIV/AIDS.

Traditional gender roles and power relations in churches have contributed to social constructs within which the subordination of women flourishes. This has, among other things, led to sexual and economic disempowerment of women, making them more vulnerable to HIV infections.

It is sad that the secular society in general, and the South African constitution in particular, had to remind the church about gender equity, when Jesus' words and actions challenged discriminatory and oppressive practices thousands of years ago. The inclusion of women in the leadership of (some) churches should not be used as a tokenist tool to make superficial adjustments. Gender frameworks must be used to promote profound, longlasting transformation. Gender hierarchies and inequalities are still dominant in many church organisations and in some instances where females are in leadership positions they take on the role of "honorary men".

In some cultures and communities issues such as legal rights, domestic violence, and women's non-control over their bodies are perceived as part of the natural order which cannot be challenged Unless women exchange knowledge with other women who know, it is impossible to change the perceived natural order of things. Women in the church, and particularly those who now occupy leadership positions, are thus encouraged and challenged to explore avenues that could have transformative and redistributive effects, that could assist all women and men in challenging unequal gender power relations in the church and society. All parishioners, including children, men and women, should be made aware of existing socially constructed gender roles that perpetuate and entrench the subordination of girls and women in the family, the church and society.

\subsection{Collaborative endeavour}

HIV/AIDS is a medical problem with social ramifications. Do you intend giving it a theological twist?

This question was put to me recently, when I shared my research interests with fellow students and academics. However, the various HIV/AIDS projects and workshops being run by churches in many communities are indicative of the churches' realization that it cannot respond theologically, if it continues to ignore its social responsibility of education and care.

25. By this I mean that some women do not really challenge the status quo and they are reluctant to raise issues that would reveal their feminine side, for fear of not being taken seriously. 
The need for ongoing medical research for a cure for AIDS and vaccine against the virus; the need for medical treatment and care; the need to address the underlying reasons why people find it difficult and sometime impossible to access medical treatment and care; the need for continuous education on issues around the social and clinical dimensions of the epidemiology of HIV/AIDS; the need to challenge oppressive economic and social structures especially those that perpetuate poverty and gender inequality; the need to change popularly held perceptions of sex, sexuality and sexual relationships that lead to stigmatization as well as the spread of HIV/AIDS; the need to live life positively and celebrate it as a gift from God; the need to make responsible decisions about how we engage in sexual relationships; the need to see the lives of others as a gift from the same God who continues to love us in spite of our sins. These are all challenges that face all of humanity, on every level of society.

Clearly the church as a whole needs to be involved on every level, engaging with government, NGOs, other faith communities and other church denominations in a collaborative effort to respond to HIV/AIDS, employing appropriate moral discourses and implementing both proactive and reactive measures. ${ }^{26}$ The need for a collaborative effort is aptly described by Nicolson when he quotes a correspondent answering a query about AIDS work in his (the correspondent's) denomination:

My impression is that several ad hoc projects are running in South Africa and that an overall lack of co-ordination could be our biggest problem (1995:6).

Over the past five years there has been a burgeoning of donor-driven HIV/AIIDS programmes and the competition for funding by NGOs including church-based organizations are continuing. This often results in the duplication and concentration of services and programmes in some areas, while other communities, especially those in rural areas are not reached. I agree with Raiser (1997:22) who contends that Christians need to move from antagonistic competitiveness to communicative cooperation.

\section{Concluding remarks}

In this article I have attempted to show that an adequate response on HIV/AIDS would have to be based on the principles operative within an ethic of responsibility. This I have done by showing that churches' response has been primarily reactive and that a responsible response would mean a focus on proactive strategies. I have argued that a proactive response, that emphasises prevention strategies aimed at changing perceptions and attitudes, would bring about behavioural change. Since it is widely agreed that the spread of HIV/AIDS depends on social behaviour, there is hope that the spiralling effect of the disease will be interrupted, and I believe the church has a crucial part to play in this regard.

The social and economic impact of HIV and AIDS on individuals, families and communities and the possible future threat that it holds for all of humanity are dramatic challenges which need a collaborative, co-ordinated response from all levels of society. I also think that the church, as a faith community, where people gather voluntarily, is a fertile seedbed for developing responses that would address the challenge to "see differently" and behave differently.

The paradox presented by the threat that the HIV/AIDS pandemic holds to human life, as well as the opportunity it offers to reflect anew on "who we ought to be", results in a creative tension within which the church has to respond, as the resurrected body of Christ.

26. See Gustafson (1988). 


\section{BIBLIOGRAPHY}

AIDS Law Project 2001. HIV/AIDS and the Law: A Resource Manual. Cape Town: Mills Litho.

Curran, CE 1976. Catholic Moral Theology in Dialogue. Notre Dame: University of Notre Dame Press.

Disaster Management Training Programme: Introduction to an Overview of Disaster Management. Johannesburg: Technikon SA.

Gustafson, JM 1975. Can Ethics be Christian? Chicago: The University of Chicago Press.

Gustafson, JM 1988. Varieties of Moral Discourse: Prophetic, Narrative, Ethical, and Policy. Grand Rapids: Calvin College.

Huber, W 1993. Toward an Ethic of Responsibility. Journal of Religion 73/4, 573-591.

Holloway, A 1999. Introduction, in Holloway, A (ed.), Risk, Sustainable Development \& Disasters. Cape Town: Logo Print.

Jegillos, S 1999. Fundamentals of Disaster Risk Management, in Holloway, A (ed.), Risk, Sustainable Development \& Disasters. Cape Town: Logo Print.

Mouton, AEJ 1994. Reading Ephesians: criteria toward a Renewed Identity Awareness? Neotestamentica 28(2), 359-375.

Mouton, AEJ 1995. Reading a New Testament Document Ethically: Toward an accountable use of Scripture in Christian Ethics, through analysing the transformative potential of the Ephesians Epistle. Doctoral Thesis. University of the Western Cape.

Nicolson, D 1995. AIDS: A Christian Response. Pietermaritzburg: Cluster Publications.

Diocesan Synod of the Diocese of Cape Town. Conference. 59th Session of the Diocesan Synod of the Diocese of Cape Town. Cape Town: Church of the Province of Southern Africa.

Niebuhr, HR 1963. The Responsible self: An Essay in Christian Moral Philosophy. New York: Harper \& Row.

Raiser, K 1997. To be the Church: Challenges and Hopes for a New Millennium. Geneva: WCC Publications.

Republic of South Africa. 1999. White Paper on Disaster Management. Pretoria: Government Printers.

Saayman, W 1991. Some reflections on Aids, ethics and the community in Southern and central Africa. Theologia Evangelica XXIV(3), 23-29.

Saayman, W \& Kriel, J 1991. Toward a Christian Response to AIDS. Missionalia 19:2, 154-167.

Smit, DJ 1991. The Bible and Ethos in a New South Africa. Scriptura 37, 51-67.

Smit, DJ 1997. Liturgy and Life? On the importance of Worship for Christian Ethics. Scriptura 63, 259-280.

Snidle, H 1997. HIV/AIDS: An Introduction, in Snidle, H \& Yeoman, D (eds.), Christ in AIDS, 17-26. Cardiff: Cardiff Academic Press.

Tsele, M 2002. The Churches' contribution to the HIV/AIDS Debate. Paper presented at the SACC Ecumenical HIV/AIDS Consultation. Kempton Park Conference Centre, 8-10 April 2002.

UN General Assembly Special Session on HIV/AIDS. June 2001.

UNICEF. Children Orphaned by AIDS. Dec 1999. 
Vosloo, RR 1997. Back to Virtue? Some remarks on the reappraisal of virtue in Ethics. Scriptura 63, 299 - 310.

World Council of Churches 1997. Facing AIDS: The Challenge, The Churches' Response. A WCC Study Document. Geneva: WCC Publications.

Yeoman, D 1997. Can There be a Theology After AIDS?, in Snidle, H \& Yeoman, D (eds.), Christ in AIDS, 27 - 35. Cardiff: Cardiff Academic Press. 